\title{
Civilisations
}

Revue internationale d'anthropologie et de sciences

humaines

52-2 | 2005

Museums, collections, interpretations

\section{« We will know our nationbetter »: Taman mini and nation building in Indonesia}

\section{Michael Hitchcock}

\section{OpenEdition}

\section{Journals}

Electronic version

URL: http://journals.openedition.org/civilisations/754

DOI: 10.4000/civilisations. 754

ISSN: 2032-0442

\section{Publisher}

Institut de sociologie de l'Université Libre de Bruxelles

\section{Printed version}

Date of publication: 1 June 2005

Number of pages: $45-56$

ISSN: 0009-8140

Electronic reference

Michael Hitchcock, " «We will know our nationbetter » : Taman mini and nation building in Indonesia », Civilisations [Online], 52-2 | 2005, Online since 02 February 2009, connection on 19 April 2019. URL http://journals.openedition.org/civilisations/754; DOI : 10.4000/civilisations.754 


\title{
«We will know our nation better»: \\ Taman mini and nation building in Indonesia
}

\author{
Michael HITCHCOCK
}

\section{Introduction}

Many of the colonies and former dependencies that achieved independence in the second half of the $20^{\text {th }}$ century are amalgams of diverse peoples with distinctive languages and customs. In common with the older established countries, these emergent nations have looked to exemplary pasts to construct narratives justifying their birth and continued existence. Much has been written about the role of « invented traditions » (Hobsbawm and Ranger, 1983) and « imagined communities » (Anderson, 1983) in the evolution of the modern nation state. Diverse and locally bound cultures in these new nations are superseded by standardised cultures, usually carried by literacy (Anderson, 1983; Gellner, 1983 ) and choices made by the state are embodied in state supported productions such as the construction of national monuments (Wood, $1984: 366$ ).

As part of the process of nation building the founders of these new countries had to create and project symbols of unity both their own people and the world at large and these have commonly been expressed in the following ways : the launching of a flagship carrying airline; the construction of grand capitals laid out according to symbolic principles; the inauguration of schools and universities bearing the names of illustrious national ancestors. Another popular medium of national construction is the national exhibition or world fair and its modern offspring, the theme park and in particular the Asian hybrid, part open-air museum and part theme park that has been discussed at length by Hendry (2000). Such complexes may be understood as forms of codification, involving new kinds of expression to address the realities of an emergent nation (Hefner, 1994 : 94) and as statements of the officialdom that builds them (Anderson, 1973).

Perhaps one of the most striking examples of this kind of hybrid museum is the exhibition complex near Jakarta, known as Taman Mini Indonesia Indah, which can be translated as «park of beautiful Indonesia in miniature » and is usually referred to as Taman Mini for short. Build at the behest of Indonesia's second president, Soeharto (196898) and his wife Ibu Tien Soeharto, Taman Mini was designed to portray the diversity of Indonesia's population and serve as a showpiece of the state philosophy of Pancasila (five principles devised by the state for political and social rule). The project was intended 
to raise awareness of Indonesia among tourists and to bolster national consciousness; as Soeharto explained in the well-known Pertamina speech of January 6, 1972, new things were needed to enhance Indonesian pride since there were so few remains of Majapahit and Sriwijaya (Anderson, 1973 : 65). The audience for which Taman Mini was intended was primarily domestic as opposed to foreign (Picard, $1997: 10$ ), though the attraction of foreign tourists is mentioned in the preface to the official guide to Taman Mini (Tien Soeharto, 1975 : 13); as early as 1969 the country's leaders had envisioned tourism as contributing to the process of nation building (Adams, 1997 : 156), which a combination of state propaganda and Taman Mini was designed to consolidate (Wood, $1997: 20)$.

A strong nation-building theme can certainly be detected in the presidential welcome address in the official guide in which Soeharto wrote : «By visiting this Park we will know ourselves better, we will know our nation better and we will love our motherland more. Therefore the « Beautiful Indonesia » Park is also a real effort to strengthen national development, both now and in the future » (Soeharto, $1975: 9$ ). There was also a strong emphasis on cultural conservation and an interest in using the park to market, stimulate and develop regional handicrafts and to « encourage communications, mutual knowledge and understanding among nations » (Tien Soeharto, $1975: 13$ ).

\section{The Inspiration for Taman Mini}

Taman Mini comprises a collection of « traditional » buildings built around a lake and has much in common with the hybrid museum-cum-theme parks discussed by Hendry (2000), though it also resembles the Skansen type open air village museums that became popular in Europe in the early $20^{\text {th }}$ century. Mrs Tien Soeharto is credited with coming up with the idea of building Taman Mini after having seen « ...such tourist attractions as Disneyland in the United States and Timland in Thailand " (Apa dan Siapa Indonesia Indah, $1975: 21)^{1}$. The so-called Projek Miniatur Indonesia Indah (Beautiful Indonesia in Miniature Project) was to be developed by Jajasan Harapan Kita (Our Hope Foundation), which was chaired by the President's wife (Anderson, 1973 : 64). In late August, 1971, Mrs Soeharto attributed her decision to build the complex to the sudden inspiration that occurred during a recent visit to Disneyland :

« I was inspired to build a Project of that sort in Indonesia, only more complete (lengkap) and more perfect, adapted to fit the situation and developments in Indonesia, both « materially » (materiil) and « spiritually » (spirituil) » (Pemberton, $1989: 215)$.

No mention of European prototypes is mentioned in her declaration but this lack of acknowledgement does not rule out European antecedents, not least because there is a well-known museum based on traditional buildings in Denpasar in Bali, which was founded in 1932. Known as the Bali Museum, it comprises a series of walled courtyards linked by gateways; each of the courtyards contains a pavilion representing the districts of Buleleng, Karangasem and Tabanan, as well as a more general archaeological pavilion. Of particular interest is the Buleleng Pavilion, which contains textiles and weaving equipment, and was originally built for the Dutch colonial exposition in 1914. The parallels with Taman Mini are striking.

1. Anderson also considers the possibility that Mrs Suharto was influenced by a visit to Bangkok in 1970 where a similar project (Timland) had been inaugurated (1973:64). 
The Dutch may have been responsible for introducing the museum concept to what was to become Indonesia, but it was not until well after the formation of Suharto's « New Order » government that museum building on a monumental scale began in earnest. Taman Mini was the first major development and cost an estimated cost of US\$26 million (May, 1978 : 277). Mrs Soeharto announced the scheme in November 1971 amid polite protests and small student demonstrations, though it was widely condemned in private as a waste of national resources. By May 1971, some of the people who had been compelled to move to make way for the project complained to the Lembaga Bantuan Hukum (Legal Aid Institute) that they were forced to sell their land to Harapan Kita for less than half the market value and that the land they were being compensated with was poorer quality (Anderson, 1973 : 64-65). The drafting of a master plan was assigned to a company called Nusa Consultants by a latter from the Hope Foundation dated 11 August 1971 and the entire plan was completed in three and a half months on 29 November.

On December 16, 1971, a delegation from the newly created Economising Movement (Gerakan Penghematan) forwarded a "Project Miniature Protest » to the National Planning Development Board. They criticised the project as «grossly luxurious» and as a waste of funds that could be better spent on either fifty-two small factories (each employing a hundred workers) or seven university campuses each the size of the distinguished Gadjah Mada University (Pemberton, 1994 : 243).

When it was realised the project would feature a model of the Indonesian Archipelago built to scale, surrounded by full-size renditions of traditional regional houses and other buildings, on a site measuring approximately 1350 by 580 metres near Jakarta. In a lavish brochure, Mrs Tien Soeharto placed emphasis on her desire to « develop and deepen the love of the Indonesian people for their fatherland », though the first promotional point mentioned was the attraction of tourists (May, $1978: 277$ ). It was estimated that Taman Mini would attract around two million visitors year on completion, rising to five million by 1978 with roughly two thirds being drawn from Jakarta and a quarter from elsewhere in Indonesia and ten per cent from abroad (Apa dan Siapa Indonesia Indah, 1975 : 34).

The centrepiece of Taman Mini was the scale model of Indonesian Archipelago, set in a lake, which included a « tall and dignified monument » to reflect the national philosophy of Pancasila (May, $1978: 277$ ). The project was created to celebrate the national motto of bhinneka tunggal ika, "unity in diversity ", and to draw attention to Indonesia's exemplary traditional culture.

In 1975 a 174 hectares site was cleared near Jakarta, and 27 pavilions were erected, representing the provinces of Indonesia. The 300 families whose houses and gardens were razed to make way for the site complained that the compensation, fixed by the sponsors at 100 Rupiahs per square metre, was insufficient (May, 1978 : 278). Adnan Bujung Nasution's legal aid/public defence institute became involved in defending the householders, but did not pursue the matter. At the height of the dispute, powerless though the homeowners were, Mrs Soeharto claimed that she would go on fighting for her project as long as she lived (May, $1978: 278$ ).

It is just possible that the expenditure of \$26 million on a tourist project at a time when Indonesia badly needed other kinds of investment (industrial infrastructure, schools etc.) was justified in the long run. The project was privately condemned as a waste of national resources, and critics noted that the land was purchased and the plans made public before a sound evaluation, which today would be called an « impact study », had 
been made of the scheme. Despite reassurances from the government that the museum would be examined in terms of profitability, and its benefits compared to other forms of development, the project went ahead. By 1990, when tourism in Indonesia had moved into fourth place as an earner of foreign exchange, outstripping rubber and coffee, these objections had largely been forgotten.

With hindsight it would appear significant that the first major open protest against New Order rule should concern a cultural village theme park. New Order propaganda is characterised by a " highly articulate rhetoric of culture ", in which constant appeals are made to « traditional values» and « customary behaviour». Advanced in the name of "social stability» these policies are doubtless seen as enhancing state security (Pemberton, 1994 : 244).

In order to appreciate why Taman Mini should serve as a showpiece of Indonesian identity, it is necessary to briefly consider how the nation came into being. It is important to note that Indonesia's political space was created as a result of many centuries of Dutch colonial interference in South-East Asia, which came to a halt during the first two decades of the $20^{\text {th }}$ century, laying the borders of what was to become the Indonesian motherland (Hubinger, 1992: 14). The inhabitants of this vast region, regardless of their ethnic or religious affiliation shared Dutch colonial rule, and this introduced a kind of negatively defined consciousness of an entity known as «Indonesia ». According to Hubinger, Indonesian nationalism is a created reality, which is derived from the Herderian brand of nationalism, in which the nation's founders are the people, the " folk» (1992:4). This drive to create a national consensus and codification of diversity under Suharto resulted in what Picard (1997 : 198) refers to as a conspicuous folklore-ization of culture, and it thus useful to contrast Taman Mini with earlier folkloric projects in Europe.

\section{Nationalism and Museology in Europe}

One museum that is closely associated with the quest for national expression, and which has been globally influential, is Skansen near Stockholm. It may be a long time since the Swedes had to struggle to assert themselves but questions of national identity have remained important since the early $19^{\text {th }}$ century, when Sweden lost Finland to Russia, up until the present (Bohman, 2000 : 275). A manifestation of these concerns can be seen in the museology of Artur Hazelius, and the establishment of the Nordic Museum. Hazelius may have emphasised the history of Sweden's kings and great artists, but it was above all peasant culture that served as desirable national model, the antithesis of the treadmill of urban industrialisation (ibid.) What is also worth noting is that Hazelius wanted, among other things, to purify the Swedish language of foreign loanwords (Hudson, 1987 : 120). There was widespread agreement that Swedes should learn about themselves primarily through the unsullied and unsophisticated character of rural communities. As a consequence the cultural heritage that was collected an exhibited would comprise items related to what was seen as the simple life of the countryside (Bohman, 2000 : 276). Hazelius's interest in rural ethnography dates from the 1850 s and 1860s when he travelled in Sweden's rural hinterland, noticing that the traditional forms of village life were disappearing as a result of the growth of industries and modern communications. Hazelius started acquiring objects in the 1870s and eventually mounted a small exhibition in Stockholm. Hazelius was convinced that if future generations were to be able to understand what Sweden had 
been like, then collections had to be formed before the material disappeared. The museum was to provide a vital link between the ancient and modern.

Hazelius arranged for the purchase of the site known as Skansen in 1891, the original displays comprising two wooden and stone cottages, as well as a Saami camp and two charcoal burners' huts. Development continued with the purchase and re-erection of buildings from all over Sweden. This nationalistic museology was further strengthened in 1893, when Hazelius instituted the Swedish National Day to be celebrated at Skansen (Bohman, 2000 : 276). Houses, farms, workshops and mills were reassembled at Skansen and in 1911 an open-air theatre was added. In contrast to Skansen, the original core of Taman Mini does not contain buildings devoted to production, though handicrafts are evident everywhere, but it does serve as a venue for the performing arts. What also distinguishes Taman Mini from Skansen is that the buildings in the former are new, or at least of 1970s and 80s vintage. When asked whether or not Taman Mini really was a museum because it comprised mainly new objects, Mrs Suharto is said to have replied : « We may call it a museum now because someday everything in it will be antique " (Pemberton, 1994 : 256).

Hazelius' approach was undoubtedly highly original, but he was not working in an academic vacuum. Hazelius' approach was in keeping with the intellectual climate of the time. For example, at the same time that Hazelius was formulating his ideas, the German scholar, Ferdinand Tönnies, was working on his book Gemeinschaft und Gesellschaft (1887). Tönnies was born into a North German rural family and had an abiding interest in the development of rural life. Like Hazelius, Tönnies was interested in describing the way of life of ordinary people in North Germany and the changes that were taking place in response to increasing urbanisation and industrialisation.

With hindsight, Hazelius' ideas seem somewhat romantic, if not a little naive, and there is a folksy quality about Skansen that has more to do with European ethno-nationalism than serious Swedish ethnography. Skansen reflects how Hazelius and his nationalist oriented folklorist movement wanted us to see Sweden, though one cannot dismiss the quality of some of the underlying ethnographic research. Hazelius' concept spread rapidly and the early $20^{\text {th }}$ century saw the introduction of Skansen-type museums across the length and breadth of Europe. Open air museums dedicated to the lives of ordinary people were, for example, opened in the Netherlands (Arnhem) in 1911; Latvia (Riga) in 1924; Wales (St Fagans) in 1949 and in Ulster (Cultra) in 1958 (Hudson, 1987 : 125-127). Open-air museums inspired by the example of Skansen, but not necessarily the folklife principles advocated by Hazelius, were also set up in North America. Perhaps the most striking similarities between Skansen and one of its descendants is encountered in Romania.

The opening of the Village Museum in Bucharest in 1936 represented the culmination of ten years of research under the leadership of Professor Dimitrie Gusti. Mixed disciplinary teams of sociologists, ethnographers and students recorded the customs and culture, and particularly material culture, of the inhabitants of forty Romanian villages, under the supervision of Victor Ion Popa and H. H. Stahl. Traditional houses were taken down and reassembled in the museum by craftsmen from their villages of origin, the research teams also made collections in each of the villages, supported by careful documentation and photography. The researchers set themselves the task of recording Romanian popular culture by showing the daily activities of a « ... householder's family from each village » (Negota, 1986 : 21). Like Skansen, and later Taman Mini, the Village Museum was built 
beside a lake near a major urban conurbation that had a poor, rural hinterland. Romania is also multi-ethnic, but unlike Indonesia its national identity is closely associated with the majority ethnic group, the Romanians.

Despite their popularity, these village museums are not without their critics. Hudson, for example, asks whether or not dancing and farm animals can really bring to life the world of $19^{\text {th }}$ century Sweden ? The cultural context of Skansen has changed and the society that visitors see in the museum today is more remote their experience than it was from the first urban visitors who went there. Modern Skansen is more exotic than it was a the time of its foundation and a greater effort is required on the part of the visitors to imagine what life must have been like in reality (Hudson, 1987 : 124). As G. B. Thompson has noted, there are two in-built weaknesses in folk village movements. First, the transfer of materials to the museum may romanticise them, especially when they are restored and kept in good repair. When the buildings are cleaned up, many of the unpleasant associations that they had for the people who once lived in them, are removed. Second, only a special kind of society is represented - rural society. Hazelius felt that it was the rural way of life that was disappearing and townspeople tended not to be represented. There were also practical considerations since it was usually only rural buildings that could be transported because they were wooden (Hudson, 1987 : 125). In practice, attention is devoted to the material culture of the pre-industrial age and what we are left with is a collection of attractive buildings. Parallels may once again be drawn with the newer cultural village museums of the Asia-Pacific region where the friendly inhabitants «never wore rags » and « the poorest workers » are « decked out in special occasion dress » (Wood, $1984: 367)$.

\section{A Museum of Indonesian Provinces}

For Indonesian nationalists of the Soeharto era, the creation of a united nation state involves either shedding " ethnic » identities (seen as symbols of backwardness within the process of modernisation) or re-conceptualising them as part of the nation's past, its « folk culture » and hitherto « living traditions ». In the development of Taman Mini these traditions are to be displayed and admired by both the local and international public. This represents a continuation of the earlier European practice of celebrating the nation's brilliant present and admirable past through exhibitions (Hubinger, 1992 : 7). Taman Mini was conceived by the Soehartos as evidence of a vital cultural inheritance (Pemberton, 1994 : 255), presenting varying aspects of nationhood and, through its exemplary displays, shows a kaleidoscope of peoples held together by nationalistic rhetoric. As in Skansen to theme of salvaging something for the future is also detectable, with Tien Soeharto describing it as « ...a priceless heritage for coming generations » $(1975: 13)$ and that « ...effort is increasingly needed before they all disappear, before the generation that understands them is no more " (ibid.) Although the outward appearance of these museums closely resembles their European prototypes, their underlying philosophies differ greatly.

In her preface to the official guidebook Mrs Tien Soeharto wrote about developing regional and national culture and arts « ... adding more beautiful colour to our national culture » (1975: 13). What may have been relevant within this context appears were the ideas of Dewantara who actively promoted the development of many regional cultures that would subsequently contribute to the emerging national culture. Together these cultural peaks, puncak-puncak dan sari-sari kebudayaan, would lay the rich foundations 
of a unique national culture (Nugroho-Heins, 1995: 16-17). The rough edges that characterised real social relations between the different ethnic groups had to be smoothed over so as not to obscure the objectives of national unity (Selwyn, 1993: 118). Wood argues, moreover, that the lack of emphasis on real ethnicity may mask Javanese political supremacy and Chinese economic dominance (1997: 26). References, however, to the centrality of Javanese culture to Indonesian national construction in the minds of Taman Mini's founders can be detected, especially with regard to the central audience hall. Comprising an exaggerated replica of a Central Javanese pavilion the building bears a Javanese (Pendopo Agung Sasono Utomo) as opposed to Indonesian name (Pemberton, 1994 : 249). In contrast, the presence of the Chinese is obscured in the government's tourism promotion literature and is overlooked at Taman Mini (Wood, 1997 : 26).

Foreign Affairs advanced a policy of cultural diplomacy, which rapidly became known as gamelan diplomacy after the Indonesian gong orchestras that travelled the world in the 1980s and early 1990s advertising Indonesia's cultural riches. The aim was to utilise the nation's cultural riches to promote Indonesia broad as a country of « high culture ». In accordance with their policy, the Indonesian dance troupes that were sent on tours were « expected to serve as artistic missions (misi kesinian) to simultaneously develop international tourism and promote Indonesia's cultural image (Picard, 1993 : 92 , Picard, 1992 : 47). As a recognised «cultural peak» Bali, for example, was supposed to represent Balinese identity on one hand and Indonesian identity on the other, and thus Balinese culture was placed in a similar position with regard to both tourism and Indonesian nationhood (Picard, 1993 : 94).

Picard further argued that there is no space in Indonesia for diversities that assert the competing economic and political claims of different ethnic groups (1997: 197). The state subscribed to the view that one is not dealing with ethnic cultures per se, but what Indonesian officials refered to as regional cultures, kebudayaan daerah. The former term, kebudayaan, may be translated as culture, but conveys the sense of those qualities commensurate with the civilization ideals of the Indonesian nation. The latter term, daerah, means « region », but is ambiguous with regard to the ethnic and geographic realities of the place under consideration (Picard, 1997 : 198). The regime emphasises culture not politics and obscures real differences (Geertz, $1990: 84$ ). In the manner of the colonial power that preceded it, the New Order government reduces the risk of mobilization along ethnic lines and defuses potential political opposition (Picard, 1997 : 197-8). By deflecting ethnic loyalties from their origins and focusing them on the province, the state provincializes ethnicity, and moves the locus of identification « from a primordial to an administrative entity' (Picard, 1997 : 198). Taman Mini is not so much of a museum of Indonesian people, but a museum of Indonesian provinces.

Each province is represented by a house, usually a reconstruction of a palace, istana, or rumah adat, traditional or clan house, belonging to one of the ethnic groups. Guinness argues that each house may contain an amalgam of architectural features or furnishings from the constituent ethnic groups of each province (1994: 271). The architectural integrity of the buildings in Taman Mini merits further investigation, but the following description of the pavilion representing the province of Nusa Tenggara Barat partially confirms Guinness's observations. The province comprises two major islands, Lombok and Sumbawa, and a host of smaller ones, but the portrayal is biased towards Sumbawa. The provincial house is a replica of the palace in Sumbawa Besar, the original building 
having been renovated in 1981 with the loss of much of its elegant carving. The detail on the replica is not as complex as on the original before restoration, but as a result of the salvage work the two structures have come to resemble one another more closely. The original palace was built by the Tau Semawa, Sumbawanese, of West Sumbawa, but the interior display showing a wedding reception refers to the Dou Mbojo, Bimanese, of the east of the island. Artefacts from Lombok are included in the exhibition, but the overall impression is skewed in favour of Sumbawa. The displays are also mainly concerned with lowland court-based societies at the expense of the provinces numerous upland and coastal ethnic minorities. The exhibition does not, however, set out to deceive since the different elements, where they are labelled, have accurate captions.

How objects used in the displays inside the pavilions were collected remains unclear, but one does not get a sense of the thorough ethnography adopted by the creators of Skansen-type museums. It would appear that it was delegated pretty much to the provinces themselves to decide what to include. In Lampung, for example, it seems to have been left to the governor's wife, who was personally interested in local textiles, to make a selection suitable for the province's pavilion, and the outcome, as was the case in many pavilions, was unrepresentative of the province as a whole with a focus on tapis cloth (Marie-Louise Totton : personal communication).

The sense that Taman Mini was designed to be understood in provincial terms is heightened by the way many domestic visitors experience the park. Small groups of Indonesians can be found wandering from pavilion to pavilion, observing the complexities at close quarters, but the majority, especially the schoolchildren, pass through the park in open-sided buses. The amount of information provided by the guides and drivers has to be commensurate with the speed of the vehicles, presumably leaving little space for ethnographic details. In any case, the only signs clearly visible from the roads that cut through the park are those bearing the names of the provinces. For foreign visitors taken around in this manner, the experience can be equally superficial, even when a translator is at hand. By the time the translator has translated the name of the province and attendant details, the vehicle has moved on to the next pavilion. Unaware of the discrepancy and what might be called relocated authenticity, the visitors appeared to have enjoyed the experience (Henri Chambert-Loire : personal communication).

The observation that Taman Mini seeks to codify Indonesia by means of the nation's provincial structure should not obscure the fact that the museum continues to provide an overview of the whole country.

« Seeing »Beautiful Indonesia-in-Miniature » gives one a broad picture on a human scale of these islands scattered across the equator. Visitors can see and grasp what is to be found in each of the thousands of islands of the motherland, getting a sense of actually visiting these islands themselves » (Apa dan Siapa Indonesia Indah, 1975 : 96).

This is partly achieved by means of a sky lift that passes over a map of the archipelago comprising miniature islands defined by concrete walls and set in the central lake. From this vantage point the visitor is expected to grasp the geo-political fundamentals of the nation and gaze downwards on Taman Mini, appreciating its completeness. Refurbishment of the cable cars during the mid 1990s involved the replacement of the lower level transparent screens with solid ones and, because of the lack of visibility in the bottom half of the cable car, the passenger is forced to look to the sides of the lake. The spectacle is presumably one that was unintended by the founders of Taman Mini. Over the years the village has become surrounded by a ring of newer museums built in steel 
and concrete, many of which are devoted to scientific and technological topics. With its thatched roofs and wooden walls, Taman Mini increasingly resembles a late $20^{\text {th }}$ century Indonesian village, steadily encroached upon by the forces of modernity : the experience is graphically Tónnies-ian.

Modelled on European and American forerunners, Taman Mini provides space for a tangible and symbolic expression of modernization. Like its Western forebear, however, Taman Mini also mixes time zones and places emphasis on the products of the preindustrial age; hand-made goods are reassuringly authentic and provide a tangible link to the past. Like Disneyland Taman Mini also contains a fairytale castle (Istana AnakAnak, Indonesia, Indonesian Children's Palace) that is completely out of keeping with indigenous Indonesian themes and seems to have more in common with the romantic extravaganzas of King Ludwig of Bavaria. The link is perhaps not so strange when one considers that Ludwig's $19^{\text {th }}$ century castle at Neuschwanstein, which celebrates a German, and specifically Wagnerian, heroic past, appears to have been a model for Disney's cartoon castles and was featured in films such as Chitty Chitty Bang Bang (1968). The castle crops up again in Taman Mini where elements of an exemplary past are portrayed as an integral part of the future in a rapidly developing nation state.

What is significant is that each province, in common with the other 27 Indonesian provinces that are represented in Taman Mini, is expected to provide nuances of colour (aneka warna) to the national culture (Picard, 1993: 92). The point being that the province and not the ethnic group has become the source of culture; not a state within a state, but a regional culture, kebudayaan daerah, an integral part of the cultural heritage of Indonesia. What should not be overlooked, however, is that Taman Mini also serves a very useful purpose, in that it provides visitors and local people with an introduction to the complexity of Indonesia as a nation. Taman Mini is also a genuinely popular recreation area, providing open spaces and variety within the highly urbanised conurbation of Jabotabek, as Jakarta and its neighbouring towns are collectively known.

\section{Conclusion}

The origins of museums such as Taman Mini can be partly located in Europe, albeit adapted to local needs and resembling the hybrid museums-cum-theme parks discussed by Hendry (2000). Taman Mini certainly has something in common with open-air museums such as Skansen where museology and nationalism were combined. Like Taman Mini, Skansen was built close to the national capital, Stockholm, and comprised a group of traditional buildings set around a lake. What is also significant is that Skansen attempts to link culture to the environment, showing how earlier generations of Swedes laboured to cultivate the land with the help of, but also in a struggle against, nature. Similar themes can be detected in Taman Mini, particularly with regard to the Indonesian vision of the natural environment as an integral part of the political one. Taman Mini is built to replication the Indonesian archipelago in a country, which regards both land and water (tanah air kita, our land and water) as an essential part of its sovereignty and identity. Taman Mini constructs a model for what Indonesia should be, « .... political text of nationalist selfrepresentation » (Errington, $1998: 201$ ), but cannot been seen totally in these terms.

Taman Mini is not devoid of serious ethnographic references, but in common with other ethnographic museums that adopt an overarching theory, it risks becoming a museum of a particular period, in this case Soeharto's New Order government. The provincial 
pavilions that comprise the heart of Taman Mini, unless they are allowed to evolve and reflect Indonesia's changing social and cultural realities, not least the ongoing devolution of power to the districts by-passing the provinces, Taman Mini may simply be relegated to a showpiece of the early part of the Soeharto era. Instead of remaining « ancestors of the future » (Pemberton, $1994: 249$ ), the pavilions may over time become « ancestors of the past », the relics of a discontinued lineage with no links to the present. Taman Mini has also grown considerably since the collection of provincial pavilions was installed and has acquired a vast array of new museums and display areas. A calendar of events, for example, for Taman Mini published in November 1997 contains a map of the whole site divided into six colour-coded zones. The original buildings, which form the subject of this paper, belong to the first section and are simply referred to as the Anjungan Daerah (Regional Annex). A comprehensive analysis of the modern scope of Taman Mini lies beyond the confines of this paper, which is concerned with New Order nationalism, not to mention the spread of Taman Mini-like villages to other Indonesian provinces.

\section{Acknowledgements}

I am grateful to the editors and publishers of Indonesia and the Malay World for allowing me to publish this revised version of a paper that originally appeared in their journal. The reference details are as follows :

Hitchcock, M., 1998. « Tourism, Taman Mini and national identity ». Indonesia and the Malay World, 26 : 74 (June), 124-35. (http://www.tandf.co.uk/journals).

I gratefully acknowledge the assistance received in preparing this paper from the London Metropolitan University, the British Academy and the ASEAN-EU University Network Programme. My thanks are due to SOAS Library and the Brynmor Jones Library, Hull. 


\section{References}

ADAms, K. M., 1997. « Touting touristic 'primadonnas' : tourism, ethnicity, and national integration in Sulawesi, Indonesia ", in M. Picard \& R. Wood (eds.) Tourism, Ethnicity and the State in Asian and Pacific Societies. Honolulu : University of Hawaii Press, pp. 155-180.

Anderson, B., 1973. "Notes on contemporary Indonesian political communication ». Indonesia, 16, pp. $39-80$.

Anderson, B., 1983. Imagined Communities : Reflections on the Origin and Spread of Nationalism. London : Verso.

APA DAN SIAPA INDONESIA INDAH (What and Who in Beautiful Indonesia), 1975. Jakarta.

Bohman, S., 2000. « Nationalism and museology : reflections on Swedish experience », in J. M. Fladmark (ed.) Heritage and Museums : Shaping nation al Identity. Shaftesbury : Donhead, pp. 75-286.

Boon, J. A.,1977. The Anthropological Romance of Bali, 1597-1972 : Dynamic Perspectives in Marriage and Caste, Politics and Religion. Cambridge : Cambridge University Press.

Errington, S., 1998. The Death of Authentic Primitive Art and Other Tales of Progress. Berkeley : University of California Press.

Geertz, C., 1990. « 'Popular art' » and the Javanese tradition ». Indonesia, 50, pp. 77-94.

Gellner, E., 1983. Nations and Nationalism. Ithaca : Cornell University Press.

Guiness, P., 1994. « Local society and culture », in H. Hall, (ed) Indonesia’s New Order. St Leonards : Allen \& Unwin, pp.267-304.

HefNer, R. W., 1994. « Reimagined community : a social history of Muslim education in Pasuruan, East Java », in C. F. Keyes, L. Kendall \& H. Hardacre (eds). Asian Visions of Authority : Religion and the Modern States of East and Southeast Asia. Honolulu : University of Hawaii Press, pp. 75-95.

Hendry, J., 2000. The Orient Strikes Back. Oxford : Berg.

Hobsbawm, E. \& T. Ranger (eds), 1983. The Invention of Tradition. Cambridge : Cambridge University Press.

Hubinger, Vaclav,1992. "The creation of Indonesian national identity », Prague Occasional Papers in Ethnology, 1, pp. 1-35.

Hudson, K., 1987. Museums of Influence. Cambridge : Cambridge University Press.

May, B., 1978. The Indonesian Tragedy. London : Routledge and Kegan Paul.

Negota, J., 1986. The Village and Folk Art Museum. Bucharest.

Nugroho-Heins, M. I., 1995. Regional Culture and National Identity : Javanese Influences on the Development of a National Indonesian Culture. Unpublished paper, EUROSEAS, Leiden.

Pemberton, J., 1989. An appearance of order: a politics of culture in colonial and postcolonial Java. (Ph. D. thesis, Cornell University).

Pemberton, J., 1994. «Recollections from 'Beautiful Indonesia'» (Somewhere Beyond the Postmodern). Public Culture, 6, pp. 241-262.

PiCARD, Michel, 1993. « 'Cultural tourism' in Bali : national integration and regional differentiation », in Tourism in South-East Asia (eds) M. Hitchcock, V. T. King \& M. J. G. Parnwell. London : Routledge, pp .71-98.

PiCArD, Michel, 1992. Bali : Tourisme Culturel et Culture Touristique. Paris : Editions L'Harmattan.

PICARD, Michel, 1997. «Cultural tourism, nation-building and regional culture : the making of a Balinese identity », in M. Picard \& R. E. Wood (eds) Tourism, Ethnicity and the State in Asian and Pacific Societies. Honolulu : University of Hawaii Press, pp. 181-214.

Selwyn, T., 1993. « Peter Pan in South-East Asia : views from the brochures », in Tourism in South-East Asia (eds) M. Hitchcock, V. T. King \& M. J. G. Parnwell, pp. 117-137. 
Soenarto, 1975. "Words of welcome», in Apa dan Siapa Indonesia Indah (What and Who in Beautiful Indonesia). Jakarta, pp. 9.

Soenarto, Tien, 1975. « Preface », in Apa dan Siapa Indonesia Indah (What and Who in Beautiful Indonesia). Jakarta, pp. 13-14.

Wood, R. E., 1984. «Ethnic tourism and the state, and cultural change in Southeast Asia ». Annals of Tourism Research, 11, pp. 353-444.

WooD, R. E., 1997. « Tourism and the state : ethnic options and constructions of otherness », in R. E. Wood \& M. Picard (eds) Tourism, Ethnicity and the State in Asian and Pacific Societies. Honolulu : University of Hawaii Press, pp. 1-34. 